\title{
FEATURE Corridor of migration, navigation, and innovation: The New York State Canal System
}

\author{
Lois Wright Morton and Kenneth R. Olson
}

$\mathrm{T}$ he rivers and canals of the northeastern United States were early transportation networks that settled interior "wildlands" and opened the subsistence farm economy to eastern markets. Industries and cities grew along these water courses, and although canals were replaced by railroads, it was the canal-river infrastructure of the early 1800s that transformed occupations, markets, and settlement patterns of the new country (Kalabon et al. 2013). Growing urbanization modified rivers and their watersheds to achieve new uses and goals. The processes of population growth and settlement create massive changes in the social-ecological dynamics of river uses, habitats, and landscapes (Grove 2009). About 3\% of the world population in the 1800s lived in urban areas; by the 1900s urban populations grew to $14 \%$ (Grove 2009), and today over half (55\%) of the world population lives in urban environments with a United Nations projection of $68 \%$ by 2050 . The spatial changes in settlement patterns and spider-like intrusions into "wildlands" along river landscapes are historic and modern, and are present and future challenges to water conservation and management at the rural-urban interface.

These changes are concurrent with the growth in scientific knowledge about water ecologies and shifts in human perspectives and values about the uses of rivers, lakes, and human-made water bodies. Nowhere is the shift in scientific understandings, innovation, and human views of the functional uses of water courses more apparent than a backward look brought forward of the New York State (NYS) Erie Canal System. Widespread post-Civil War canal infrastructure investments were important

Lois Wright Morton is professor emeritus of sociology in the Department of Sociology, College of Agriculture and Life Sciences, lowa State University, Ames, lowa, and Kenneth R. Olson is professor emeritus of soil science in the Department of Natural Resources and Environmental Sciences, College of Agricultural, Consumer, and Environmental Sciences, University of Illinois, Urbana, Illinois. engines of economic development and growth (Vitaliano 2016). Economic analysis of canal impacts on local and national economies from tolls, construction, wage labor, new technologies, and reduction in freight costs of raw commodities and finished manufactured products reveal net social and economic benefits at their peak (Vitaliano 2016). Today the canal system is no longer a commercial navigation system, but it is a critical water ecosystem and green open space that draws thousands of people annually to the unique and varied natural landscape of NYS.

Canals throughout NYS were constructed on the backbone of abundant rivers and lakes and the port of New York City (NYC) strategically located on the Atlantic Ocean (figure 1). Completed in 1825, the Erie Canal System linked major rivers, the Hudson, Mohawk, Oneida,
Seneca, and Oswego, and the Finger Lakes to the US Great Lakes via canal ports on Lake Ontario and Lake Erie. The NYS Canal System cut in half travel time from Buffalo to Albany, reduced freight rates $10 \%$, and made NYC the commercial center of the United States for many years (Lyons 2008).

Along with canal-river transport, economic development, human migration, and settlements came water pollution; untreated human sewage; and cholera, a deadly disease that spread rapidly in 1832 across lower Canada and eastern United States by travelers on the NYS waterways (Tuite et al. 2011). It was not until the late 1800s that public health institutions realized that polluted water was the carrier of cholera and began to press for cleaning up canal-river systems and establishment of sanitary water supplies and wastewater

\section{Figure 1}

The New York State Canal System (built and enlarged 1817 to 1880) runs west-east from Buffalo on Lake Erie to Albany where it meets the Hudson River. At Albany the canal system runs north-south, connecting the headwaters of the Hudson to Lake Champlain by canal and flowing south to the mouth of the Hudson River, the port of New York on the Atlantic Ocean.

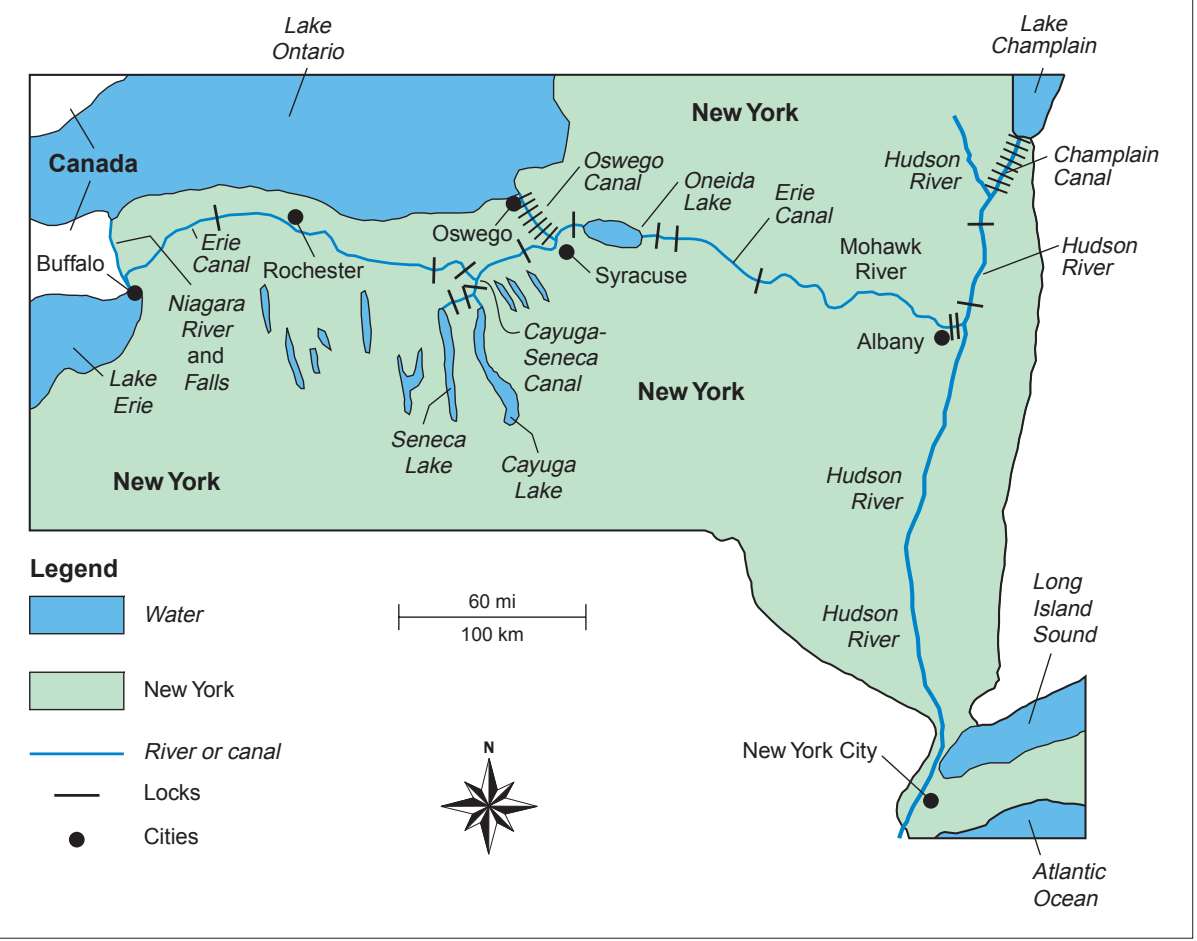


treatment systems in densely populated canal-river settlements. An unintended consequence of the canal system was the introduction of the nonnative sea lamprey (Petromyzon marinus) into the ecology of the Great Lakes and Lake Champlain. The canal became a migration pathway for sea lamprey populations from the Atlantic Ocean, up the Hudson River and via connecting canals to Lake Ontario and Lake Champlain by early 1900s (Eshenroder 2014). The arrival of the invasive parasitic sea lamprey into the Great Lakes altered the native fish stocks of Atlantic salmon (Salmo salar), lake trout (Salvelinus namaycush), and lake whitefish (Coregonus clupeaformis); and led to widespread loss of commercial fisheries (Eshenroder 2014).

By the twenty-first century, the lifecycle of the canals as a transportation network for settlers and market exchanges had matured and become obsolete. Today there are 234 cities, villages, and towns and a population of almost three million people along the Erie Canal corridor (Lyons 2008). The heritage of the canal system has left a large imprint on the people and rivers of NYS, and these water resources now represent a different kind of valued asset at the rural-urban interface. We take a look at the history of the Erie Canal System; how it transformed the physical, social, economic, and environmental landscape; and the new opportunities this unique water resource offers in an age of diminished natural resources, population growth, and increased need for protecting river ecosystems, bluegreen spaces, and watershed management.

\section{CANALS AND WESTWARD MIGRATION}

Canals, human-made channels connecting rivers and lakes, were major innovations in the United States during the early 1800s (figure 2). They expanded natural inland navigation far into the interior "wildlands" of America (Stevenson 1838). The lower Hudson and Mohawk rivers became the major migration route for Europeans settling in western NYS, northeastern Pennsylvania, and the northern section of the Ohio territory in the late 1700s and 1800s (figure 1). When American settlers arrived in the port of New York, they migrated west using the river valleys which offered a much easier route than

\section{Figure 2}

The gates are closed at Palmyra Lock 29 creating slack water in the foreground as canal boats approach the lock from the east.

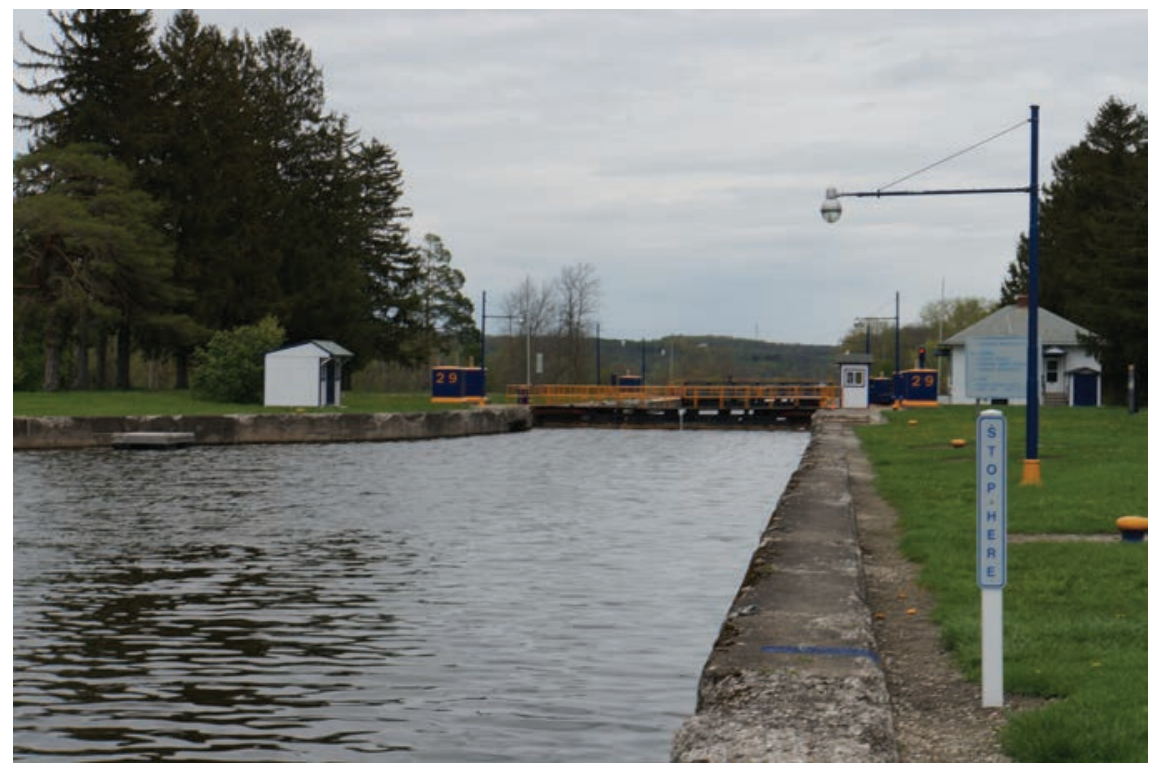

traversing the Catskill and Appalachian mountains. However, once the early settlers reached the western extent of the Mohawk River they traveled overland on poorly developed roads and paths to reach Lake Erie. By the early 1800s the State of New York funded construction of the Erie Canal from the Mohawk River to the Niagara River. This enabled European people and goods to be transported by barges on the Erie Canal and rivers from NYC to Buffalo on Lake Erie and Lake Ontario. It fueled the economic and social development of the state, decreased travel time, lowered freight costs, and opened new markets.

During the canal building years, 1817 to 1880 , existing rivers and creeks were used to create the Erie Canal. The engineering goal was to use the lowest water courses (rivers and creeks) and the natural elevation of the landscape rather than building artificial channels along the higher ground. Water courses included the Mohawk River; Oneida Lake; the Oneida, Oswego, Seneca, Clyde, and Niagara rivers; Tonawanda Creek; and Wood Creek.

Canals became extensions of rivers with water elevations controlled by building dams and locks (figure 2) and dredging channels. The dredging provided uniformity in width and channel depth, and dams maintained the surface of the water at a fixed elevation above the streambed turning the rivers into a series of pools between dams. These dams controlled the water levels on the canalized rivers at strategic locations such as the dam on the Mohawk River between Schenectady and Cohoes. The dams at Schenectady and Little Falls had gates that could be lowered or raised to adjust water levels. A series of five lifts near Waterford moved boats upand downstream a total of $52 \mathrm{~m}$ (169 ft), twice the lift of the Panama Canal, which opened in 1914.

Canals need a continuous supply of water in order to provide a dependable water course that could be manipulated for navigation. The Niagara River was adequate for the western part of the Erie Canal, but the eastern part, between Rome and Troy, lacked sufficient water in dry summers (figure 1). Two very large $11.7 \mathrm{~km}^{2}\left(4.5 \mathrm{mi}^{2}\right)$ reservoirs, the Delta and Hinckley dams built near the headwaters of the Mohawk River, had feeder canals that kept the Erie Canal supplied with water during dry periods. 


\section{GEOLOGY OF THE LAKE ONTARIO BASIN AND THE LAKE CHAMPLAIN AND MOHAWK VALLEYS}

The Ontario Lake basin, made of soft Silurian-age rocks, was created in the last ice age by the Wisconsin glacier. The Ontarian River valley prior to the glacier had a similar east-west orientation as the current land and drainage basin (figure 3 ). A southward moving ice sheet altered the region's drainage system as it scoured the lake bottom and pushed glacial till into drumlins and moraines; and left behind the eskers, kames, and kettle lakes of the present landscapes when it melted and receded (Morgastein et al. 2001).

While the southern end of the ice sheet melted, the northern section of the glacial ice sheet remained frozen for many years and dammed the St. Lawrence valley outlet. This made the lake surface a higher level than it is today. The enlarged postglacial lake, known as Lake Iroquois, drained through present-day Syracuse (figure 3) and carved out the $160 \mathrm{~km}$ (100 mi) Mohawk River valley (Ridge 1997) as it drained east and south toward the Hudson River. The enormous discharge of water during this stage scoured the area deeply and deposited sand and gravel in an area known today as the Great Flat Aquifer (Johnson 2009). The shoreline of ancient Lake Iroquois can be observed as a dry beach ridge 15 to $40 \mathrm{~km}$ (10 to $25 \mathrm{mi}$ ) from the present Lake Ontario shoreline.

The Mohawk River watershed drained a portion of the Catskill Mountains, which is a subarea of the southern Adirondack Mountains. This watershed developed in Paleozoic sediment rocks overlying 1.1 billion-year-old Proterozoic metamorphic rocks. During the Pleistocene (ca. 1.8 to 0.01 million years ago), glaciation modified the basin and left behind surficial deposits of boulders and clay-rich glacial till approximately 13,350 years ago. The headwaters of the Mohawk River begin in Lewis County and meet the Hudson River near Cohoes Falls (figure 4) and the city of Cohoes. The Lake Iroquois footprint and its glacial meltwaters offered a natural path to engineer the Erie Canal

\section{Figure 3}

Lake Iroquois, a post-glacial lake, and its melt floodwaters carved out the Mohawk River valley creating a natural path to engineer the Erie Canal.

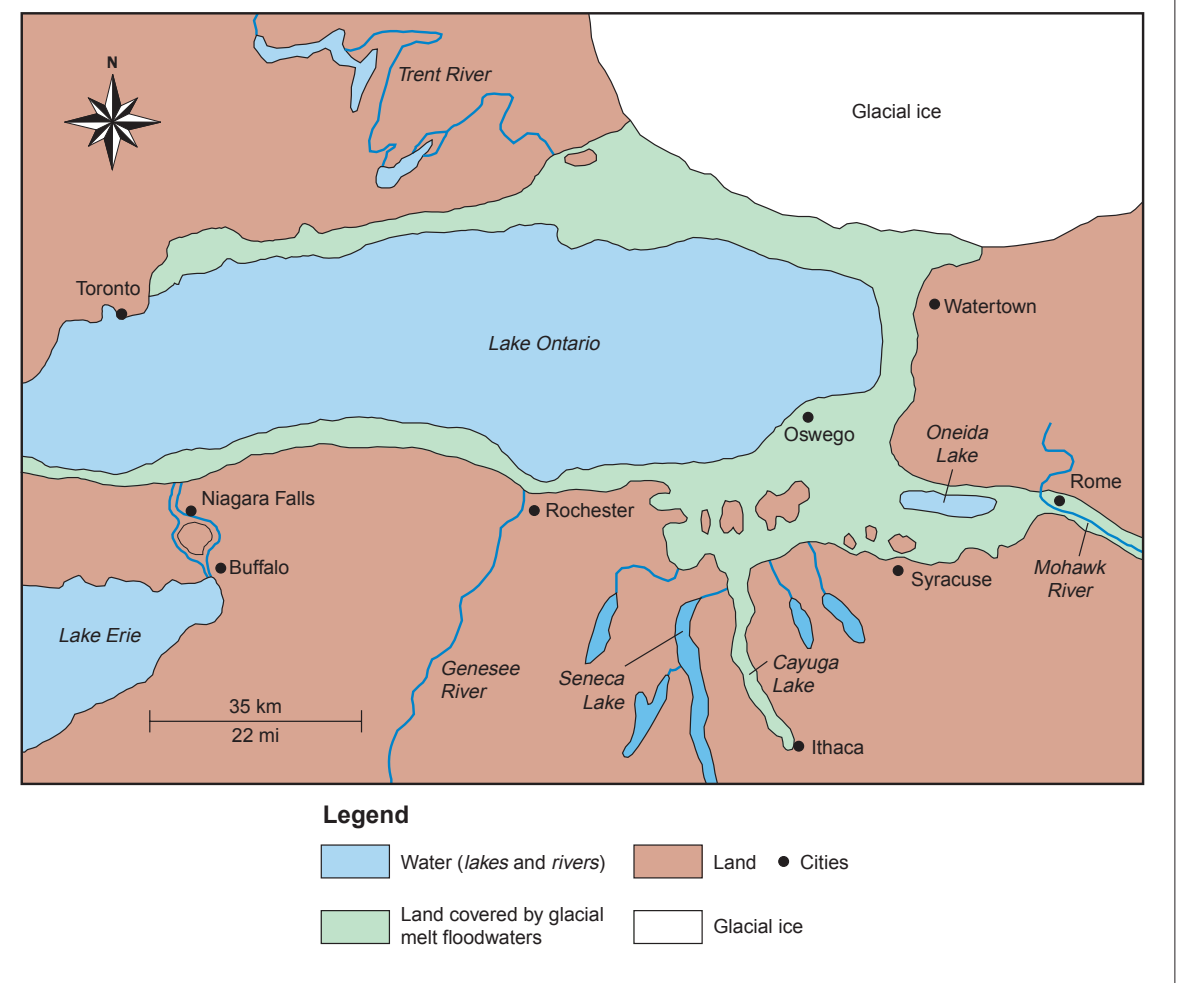

system from Lake Ontario to the Hudson River via the Mohawk River.

\section{WATERWAY IMPROVEMENTS IN NEW YORK STATE RIVERS AND CREATION OF THE CANAL SYSTEM}

The first waterway improvements made in NYS were begun by a private company in 1791 to facilitate navigation on natural rivers. Military transportation problems during the War of 1812 gave momentum to the idea of constructing a canal across the state. By 1816 it became apparent that financial aid from the federal government was not coming, so the NYS legislature passed an act in 1817 authorizing a canal from the Hudson River to Lake Erie. The Project was divided into Hudson River to Rome, Rome to Seneca River, and Seneca River to Lake Erie. The canal required the digging of a $580 \mathrm{~km}$ (363 mi) long ditch that was $12 \mathrm{~m}$ (40 ft) wide at top and $8.2 \mathrm{~m}$ $(28 \mathrm{ft})$ wide at bottom with a depth of 1.2 $\mathrm{m}$ (4 ft). Fortunately, most of the digging was in alluvial, lacustrine, and glacial till.

Lake Erie is $172 \mathrm{~m}$ (565 ft) higher than the Hudson River, and the waterway originally required 83 locks, each $26 \mathrm{~m}$ (90 ft) long by $4.5 \mathrm{~m}$ (15 ft) wide with an average lift of about $2.4 \mathrm{~m}$ (8 ft). Locks are structures used to raise and lower boats from one canal or river to another stretch of water that is at a different level; or to bypass falls and rapids (Olson and Morton 2016). The lock and dam engineering created pools of water a specific water depth (originally $1.2 \mathrm{~m}$ [4 ft] later deepened to $2.1 \mathrm{~m} \mathrm{[7} \mathrm{ft])} \mathrm{for} \mathrm{navigation} \mathrm{between} \mathrm{dams.}$ These pools were called slack-water canals. They had less current than a running stream and were flanked on one side by an elevated tow-path where a team of mules pulled the packet boats along the canal.

Nearly all the construction was done by pick and shovel labor and animal power. Gunpowder was packed into hand drilled holes to blast areas of bedrock since dynamite was not invented until 1867, long after the canal ditches were dug. The heavily forested landscape made tree and stump removal a big challenge. Other challenges included valleys that had to be spanned; ridges to be excavated; and swamps, including the Cayuga marshes (Montezuma Swamp), that had 
to be drained in the summers of 1820 and 1821. Contractors paid Irish workers US $\$ 1.25 \mathrm{~d}^{-1}$ to do this backbreaking work. One major problem in constructing stone structures for canal locks and aqueducts was locating a source of hydraulic cement that could harden under water. Both locks and waste weirs required use of cement to hold the stone in place. Common quick lime did not work under water, so initially European hydraulic cement was used. However, when Canvass White discovered a limestone near Chittenango that when burned, pulverized, and mixed with sand produced a cement that would harden under water, the cost and timely availability of cement was solved (Larkin 1998).

At Rochester, contractors encountered the Irondequoit Creek Valley and the fast flowing Genesee River. They constructed a $0.40 \mathrm{~km}(0.25 \mathrm{mi})$ earthen embankment $21 \mathrm{~m}$ (70 ft) above the valley to support the canal and a $240 \mathrm{~m}(802 \mathrm{ft})$ long masonry aqueduct to carry canal water over the Genesee River.

\section{THE NEW YORK STATE CANAL SYSTEM}

The entire NYS Canal System, also called the NYS Barge Canal, was a $845 \mathrm{~km}(525$ mi) system composed of the Erie Canal connecting the Hudson River via the Mohawk River to Lake Erie at Buffalo; the Oswego Canal connecting the Erie Canal directly north to Lake Ontario; the Cayuga-Seneca Canal running south from the Erie Canal to Seneca and Cayuga Finger Lakes; and the Champlain Canal connecting the Hudson River north to Lake Champlain, the Richelieu River, the Chambly Canal, and ultimately the St. Lawrence River (figure 1).

Originally the port of Oswego on Lake Ontario was proposed as the western terminus for the Erie Canal. However, the Welland Canal Company incorporated by British Canada began to construct a canal in 1824 between Lake Ontario and Lake Erie. New York State decided to make Buffalo, New York, the terminus for the Erie Canal to have more control of Lake Erie. The Oswego River flowing north to the port of Oswego (figure 5) formed a major portion of the $61 \mathrm{~km}(38 \mathrm{mi})$ Oswego Canal that connected to the Erie Canal in Syracuse (figure 6). Completed

\section{Figure 4}

Where the Mohawk River runs between Schenectady and Albany there is a $419 \mathrm{ft}$ drop that creates Cohoes Falls. Canal engineers originally constructed 27 locks around these falls.

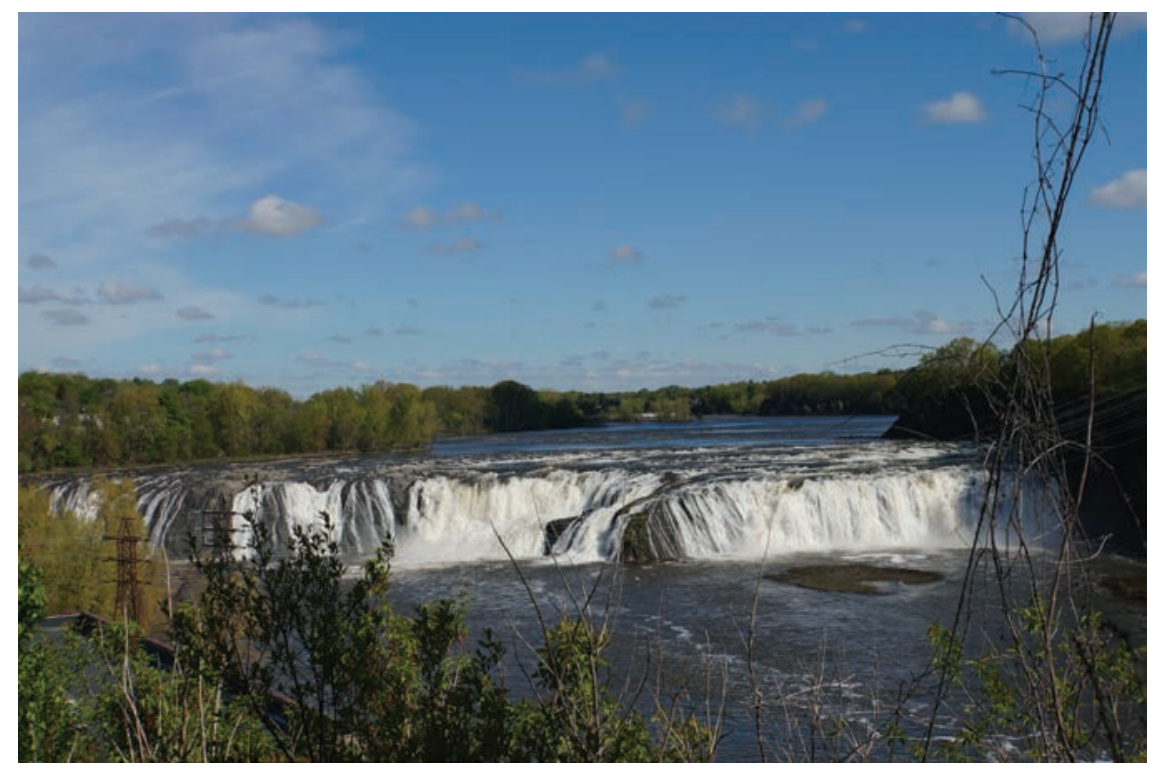

\section{Figure 5}

New York State funded construction of two modern grain elevators in the early 1900s. One was built at the port of Oswego on Lake Ontario enabling the transfer of agricultural fertilizers, grains, and other commodities; the other was the Gowanus Bay terminal in New York City.

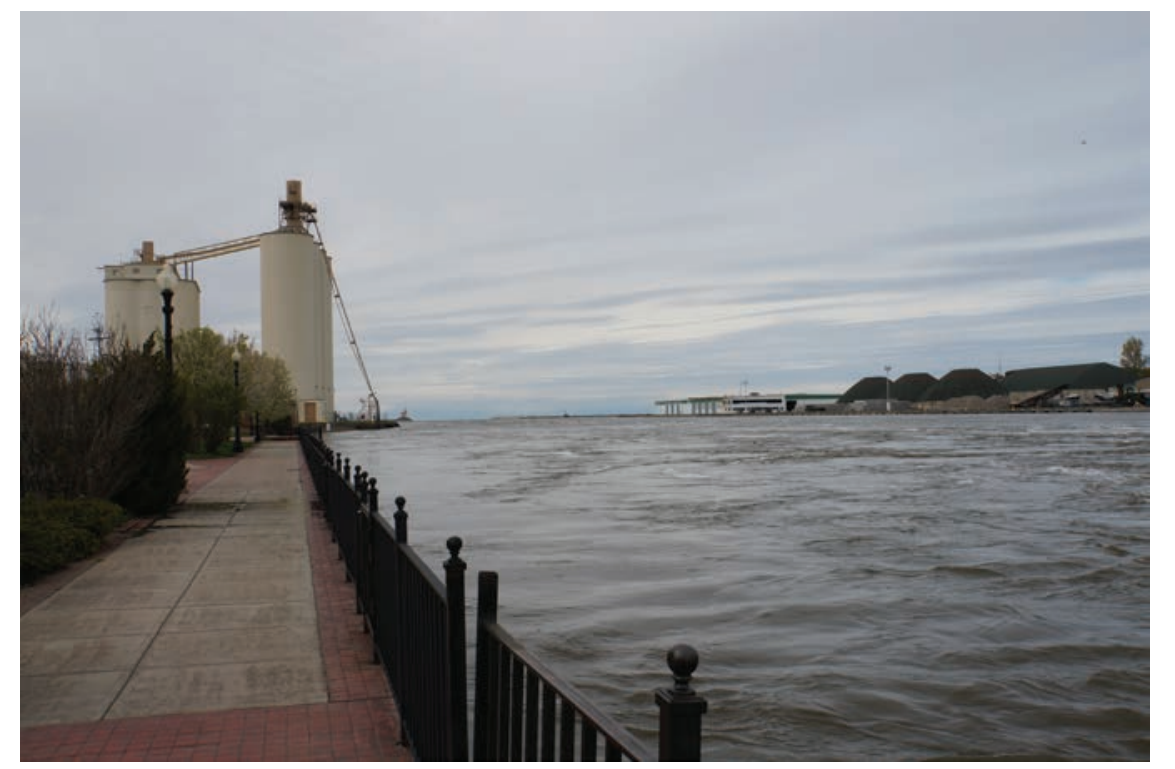

in 1828, slack water in the Oswego River was created by the construction of 18 locks (Morgastein et al. 2001). The canal cost less than US\$600,000 to build. Subsequent enlargement made it one of the most profitable canals in the system because it allowed trade with Canada via the Great Lakes all the way to the port of NYC and the Atlantic Coast. The last improvement made in the 1900s increased 


\section{Figure 6}

Canal tolls were assessed by weight. A canal boat sits in the Syracuse weigh lock where water is drained through a sluice gate at the bottom, leaving the boat to rest on a cradle scale at the Erie Canal Museum. The empty weight of the boat, on record as part of the annual state registration, was subtracted from the full weight of the boat with goods on board.

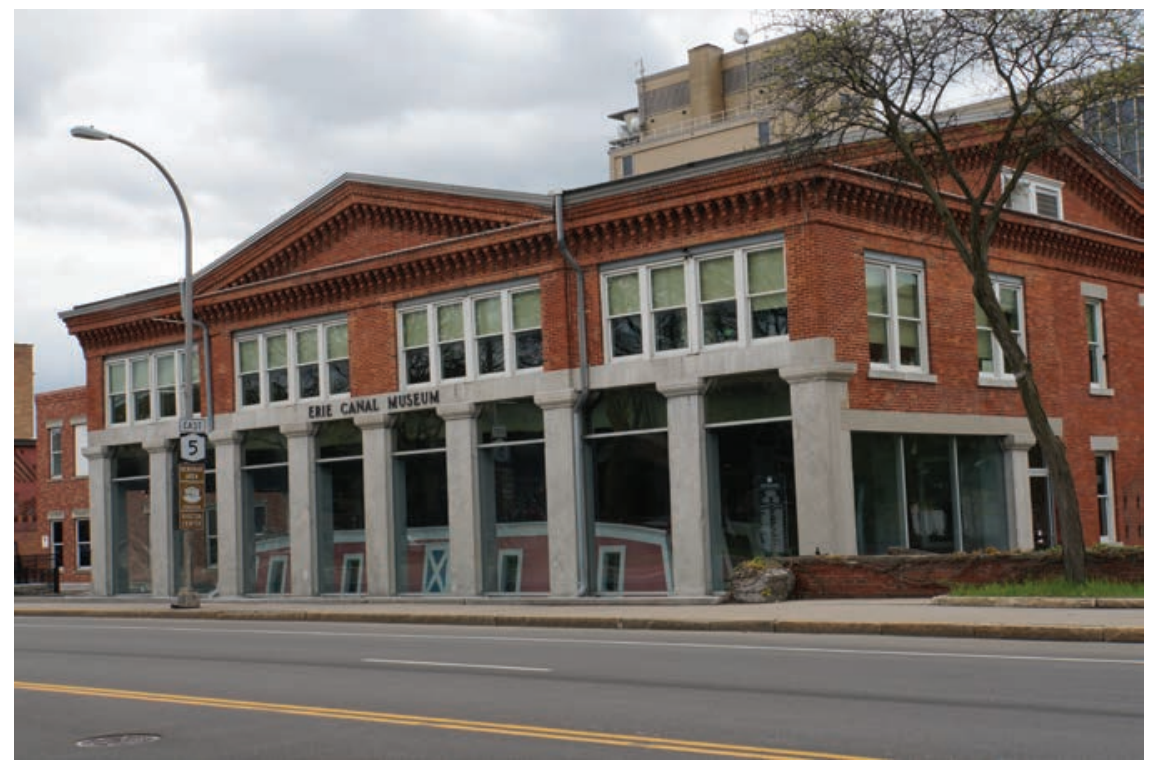

the draft to $4.3 \mathrm{~m}(14 \mathrm{ft})$ with $6.4 \mathrm{~m}(21 \mathrm{ft})$ clearance under bridges (air-draft), which today allows recreational cruisers to travel from the ocean to Lake Ontario.

West-central NYS has the two largest Finger Lakes in the state, the $61 \mathrm{~km}$ (38 mi) long Cayuga and the $56 \mathrm{~km}$ (35 mi) long Seneca. These lakes offered access to sizable territory, and their value was enhanced by connecting the Seneca River to the Erie Canal. Part of the Three River confluence north of Syracuse, the Seneca River flows north from Seneca Lake until it joins with the Oneida River to become the Oswego River. In 1792, the right to improve navigation along the water course to Seneca Lake was granted, and by 1821 improvements were made in a water route connecting Seneca and Cayuga lakes. The 35 km (22 mi) Cayuga Canal was completed in 1828 (figure 1), enabling travel between the two Finger Lakes and eastern and western NYS markets via the Erie Canal. The western part of the link from Albany followed Wood Creek from Rome to Oneida Lake, across the lake to an outlet on the Oneida River, through 16 $\mathrm{km}(10 \mathrm{mi})$ of river to its confluence with Seneca River, and $32 \mathrm{~km}$ (20 mi) down the Oswego River to Oswego. It is still used by recreational boaters today.

The confluence of the Mohawk River and Hudson River is near Cohoes Falls (figures 1 and 4) and Cohoes, NYS. From Utica east to Schenectady, the Erie Canal followed the south bank of the Mohawk River. At Little Falls, a 360 m (1,184 ft) stone aqueduct feeder canal crossed the Mohawk River enabling boats to use the north side of the Erie Canal and to feed water into the canal to maintain navigation depth. The lower part of the Mohawk River had five permanent dams, nine seasonal dams, and five active hydropower plants. Schoharie Creek and West Canada Creek were both tributaries with large dams including Hickley Dam on West Canada and Gilboa Dam on Schoharie Creek. The Gilboa Dam was completed in 1926 as part of the NYC water supply system.

\section{LAKE CHAMPLAIN CANAL}

Changes in the watercourse between Hudson River and Great Lakes were discussed during the seventeenth century, but it was not until 1792 that Western Inland Lock Navigation Company started improv- ing the waterways. One of the first tasks was to clear Wood Creek and create a lift lock at Little Falls to circumvent the falls of the Mohawk River. Funding soon became a major problem. However, with the onset of war in 1812, the NYS commissioners decided a canal between Lake Champlain and the upper Hudson River was of national importance, and the legislature provided financing to keep the company solvent.

The Champlain Canal was authorized on April 15, 1817. A total of 19 lift locks on the $106 \mathrm{~km}$ (66 mi) route between Whitehall and Lake Champlain was completed on September 23,1823, at the cost of US\$921,000. Champlain Canal was a huge success. Lands around Lake Champlain and Lake George (west of Lake Champlain) had valuable timber and there were extensive and rich deposits of iron (Fe). Both commodities were shipped by canal along with Vermont marble. More than 19,000 boats passed through in the first year. The Champlain Canal took the primary share of the western Massachusetts and Vermont trade to NYC via the Hudson River.

\section{COSTS AND ECONOMIC BENEFITS}

In the nineteenth century the Erie Canal brought business to the state as well as more than US\$120 million in tolls, which paid for the original construction cost, the first enlargement, and the first 75 years of maintenance. The success of the Erie Canal resulted in 10 laterals being built in the first 14 years. By 1862, the Erie Canal had been enlarged and deepened to $2.1 \mathrm{~m}$ (7 ft) depth. In 1882 yearly tolls were abolished; it had earned US $\$ 42$ million, more than it originally cost, including the cost of enlargements, maintenance, and operations.

The NYS legislature in 1903 authorized the construction of the New York State Barge Canal as the "Improvement of the Erie, Oswego, Champlain and the Cayuga and Seneca Canals." Construction started in 1905 and finished in 1918, at a cost of US\$96.7 million (Whitford 1922). The Erie Canal reduced freight costs by a factor of 20 and took half the time of ox-pulled wagons. In 1840 most goods went west, but by the 1860 s much of the freight went east. Competition with railroads caused canal traffic to diminish. Regardless, the Erie 
Canal had its greatest tonnage in 1880, after 50 years of railroad construction.

\section{INNOVATIVE INFRASTRUCTURE, SOCIAL, AND ECOLOGICAL IMPACTS}

"Like America, the Erie Canal was bold, innovative, and huge. Nothing of its magnitude had ever before been attempted" (Karwatka 2012). This remarkable navigation infrastructure created new towns and cities along its banks; provided hydroelectric power for new industries and residential homes; created vast new markets for agricultural, forestry, and mining commodities; and made household products less expensive and more accessible. Community building is difficult without people, raw materials, big equipment, and simple necessities. The Erie Canal brought them all together; forests gave way to sawmills and hamlets grew into villages as the settlers migrated westward.

Not only did the canal project alter systems of transportation, expand the economy, and elevate civil engineering into a well-regarded profession, it transformed other aspects of society. Canal towns became the conduit for the mixing of diverse people and fostered social reform. The canal towpath became one of the main Underground Railroad routes, which slaves used to escape to Canada. Along with abolition of slavery, other social movements emerged with women's rights (Seneca Falls) and religious revivals originating in upstate NYS. During these canal years, evangelicals had a "great awakening," a revival that gave western NYS the label the "Burned-Over District." The Seventh-day Adventist church rose from this "awakening" in upstate New York and today has over 20 million members globally. The Mormon (Latter Day Saints) religion began in Palmyra, a small town on the canal, which has become a major pilgrim destination for Mormons worldwide.

The canal altered the ecology of almost every water body in New York State: major rivers, the Finger Lakes, the Great Lakes, and smaller inland lakes. The migration of the sea lamprey, a nonnative fish species into Lake Champlain and the Great Lakes, and water-borne diseases from canal-river water in the cities along the canal were two unexpected consequences.
The growth of small towns and cities along the canal increased industrial and residential water pollution. As cities grew, human and industrial waste were flushed into rivers and canals causing typhoid and cholera epidemics (Tarr 1996; Tuite et al. 2011). The North American cholera epidemic of 1832 began in Quebec City and Montreal and quickly spread along waterways, including the recently completed Erie Canal. Lewis Beck's 1832 report documented outbreaks that occurred in sequence, "... starting with the disembarkation of infected individuals from boats plying the canals and rivers of New York" (Tuite et al. 2011). Cholera cases clustered among the poor, immigrants, and laborer populations, and early medical theories proposed it was poor people who had intemperate habits that made them vulnerable to disease (Tuite et al. 2011).

Environmental knowledge and attitudes about garbage removal, waste disposal, and water pollution were not well understood in the nineteenth century. Tarr (1996) writes that there was uncertainty on ecological and human health grounds about whether to treat sewage before discharging it into water. Scientific theories of the mid-1800s proposed that running water would purify itself, and that disease epidemics like cholera were caused by contaminated air (Tarr 1996; Tuite et al. 2011; Johnson 2006). There was no consensus that cholera was contagious or caused by untreated wastewater. It was not until the latter 1800 s that germ theory prevailed, and it became generally accepted that cholera was caused by invisible microbes in water. This new scientific knowledge spurred public health institutions to establish sanitary sewers to protect public drinking water supplies. As the cities and towns along rivers and canals built sewer systems, the smelly stench of the waterfront lessened, city drinking water tasted better, and water-borne contagious diseases were almost eliminated (Johnson 2006).

The marvel of an interconnected waterway had another unintended consequence: it bridged drainage divides and created new routes for ocean, river, and lake aquatic species to intermingle. As the canal-river system extended navigation beyond the Hudson River, it opened a water path to nonnative fish species, like the sea lamprey, to migrate upriver from the port of New York to Lake Champlain and the Great Lakes (Eshenroder 2014). After spawning up coastal rivers, sea lamprey larvae take four or more years to fully develop into adults that parasitically suck the blood and body fluids of fish (Eshenroder 2014). First observed in Lake Ontario in 1835, the sea lamprey quickly spread into all the Great Lakes with improvements to the Welland Canal that bypasses Niagara Falls (Great Lakes Fishery Commission). Native fish-lake trout, lake whitefish, and Atlantic salmon-virtually disappeared, as did thriving fishery occupations and industries, when sea lamprey populations, without natural predators, exploded. The lake trout harvest in the upper Great Lakes in the early 1960 s was $2 \%$ of the $7 \times 10^{6}$ $\mathrm{kg}\left(1.5 \times 10^{7} \mathrm{lb}\right)$ before the sea lamprey invasion (Great Lakes Fishery Commission 2018). Today there is an extensive sea lamprey control program using a combination of barriers and traps to prevent upstream migration and lampricides (pesticides) that selectively kill larvae and adults.

\section{THE NEW YORK STATE CANAL SYSTEM TODAY}

Trains and trucks have taken over the transport of most cargo that once moved on the barges of the NYS Canal system. Now pleasure boats, tour boats, cruise ships, canoes, and kayaks are the majority vessels that use the waterways of the Erie, Oswego, Cayuga-Seneca, and Champlain. The canal system serves historical and recreational purposes and provides important wetland and river habitats. The current canals are $3.7 \mathrm{~m}(12 \mathrm{ft})$ deep and $37 \mathrm{~m}$ (20 ft) long (figure 2) with 57 electrically operated locks, which can accommodate vessels up to $1,800 \mathrm{t}(2,000 \mathrm{tn})$. The canal system is open from May 1 to November 15 , and motorized craft pay a fee to traverse the locks and lift bridges. The NYS Canal System reported the shipment of $10,000 \mathrm{t}(12,000 \mathrm{tn})$ of cargo valued at approximately US\$102 million in 2004 and documented 122,000 recreational vessels locking on the canal. By 2012, the system annual cargo volume reached 
$38,000 \mathrm{t}(42,000 \mathrm{tn})$ with future projections of $180,000 \mathrm{t}(200,000 \mathrm{tn})$ beyond 2017. Hydropower continues to provide electricity to the canal system and adjacent rural and urban communities. In January of 2017, the New York State Canal Corporation became a subsidiary of the New York Power Authority.

\section{CANALS, A PUBLIC TRUST}

In NYS, the canal system, its lands, and waters were "recognized, treated, and protected 'for the commercial advancement and prosperity of the state and its people"” in 1921 (Bray 1994). New York State courts have upheld this vision and reaffirmed state ownership of canal lands as a trust for public purposes. This has state and national significance for future uses of canal-river water courses ranging from open space conservation, watershed and habitat protection, recreation, and tourism (Lyons 2008) in a state and nation with expanding populations. In 2017, the canal system had over 3.3 million visits and total revenue just under US $\$ 1$ billion. Boaters, cyclists, hikers, and paddlers are active users of the canal system, and festivals, museums, and other events are major sources of revenue (Level 7 Market Research 2017).

The multi-uses of rivers, canals, and lakes play central roles in bringing the lives of rural and urban peoples together. They provide critical habitats for plants, fish, waterfowl, animals, and people who derive their livelihoods from their water resources. They are sources of past, present, and future economic prosperity, human health, and well-being. Competing and complementary values and preferred uses give urgent meaning to water as the "new gold" and will require continued science and innovation to meet complex challenges as water resources become more limited and degradation affects all populations.

\section{ACKNOWLEDGEMENTS}

Published with funding support from Iowa Agriculture and Home Economics Experiment Station, College of Agriculture and Life Sciences, and Department of Sociology at Iowa State University, Ames, Iowa; USDA National Institute of Food and Agriculture, Water Division; and Director of the Illinois Office of Research, College of Agricultural, Consumer, and Environmental Science, Department of Natural Resources and Environmental Sciences, University of Illinois, Urbana, Illinois.

\section{REFERENCES}

Bray, P.M. 1994. The role of the public trust doctrine in planning and management of the New York State Canal System. Albany Law Journal of Science and Technology 4(1):47.

Eshenroder, R.L. 2014. The role of the Champlain Canal and Erie Canal as putative corridors for colonization of Lake Champlain and Lake Ontario by sea lampreys. Transactions of the American Fisheries Society 143:634-649.

Great Lakes Fishery Commission. 2018. Sea lampreys. Ann Arbor, MI: Great Lakes Fishery Commission. http://www.glfc.org/sea-lamprey.php.

Grove, J.M. 2009. Cities: Managing densely settled social-ecological systems. In Principles of Ecosystem Stewardship, eds. F.S. Chapin III, G.P. Kofinas, and C. Folke, 281-294. New York: Springer.

Johnson, S. 2006. The Ghost Map. New York: Riverhead Books.

Johnson, T.M. 2009. Responsible planning for future ground water use from the Great Flats Aquifer. In Proceedings from 2009 Mohawk-Watershed Symposium, Union College, New York, March $27,2009$.

Kalabon, A., E. Loescher, A. Sommerville, and N.J. Delatte. 2013. Rise and fall of the Ohio and Erie Canal. Journal of Professional Issues in Engineering Education and Practice 139:3:226-234.

Karwatka, D. 2012. The Erie Canal. Techdirections October, p. 10. http://www.techdirections.com/. Larkin, F.D. 1998. New York State Canals: A Short History. Fleischmans, NY: Purple Mountain Press. Level 7 Market Research. 2017. (Dec 15) Canal Event Analysis. Erie Canalway National Heritage Corridor. https://eriecanalway.org/.

Lyons, C. 2008. Navigating the future of the Erie Canal. Planning 74(4)10-13.

Morgastein, M., J. H. Cregg, and Erie Canal Museum. 2001. Erie Canal. New York: Arcadia Publishing.

Olson, K.R., and L.W. Morton. 2016. Managing Mississippi and Ohio River Landscapes. Ankeny, IA: Soil and Water Conservation Society.

Ridge, J.C. 1997. Discontinuity and Little Falls Gravel: Evidence for Erie interstage in central New York State. GSA Bulletin 109(6):652-665.

Stevenson, D. 1838. Sketch of the civil engineering of North America: Comprising remarks on the harbours, rivers and lake navigation, lighthouses, steam-navigation, waterworks, canals, roads, railways, bridges and other works in that country. London: Sabin Americana Gale, Cengage Learning.

Tarr, J.A. 1996. The Search for the Ultimate Sink: Urban Pollution in Historical Perspective. Akron, $\mathrm{OH}$ : The University of Akron Press.

Tuite, A.R., D.H. Chan, and D.N. Fisman. 2011. Cholera, canals, and contagion: Rediscovering Dr. Beck's report. Journal of Public Health Policy 32:320-333

Vitaliano, D.F. 2016. Benefits and costs of the Erie Canal: A new view. Eastern Economic Journal 42(4):581-593.

Whitford, N.E. 1922. History of the Barge Canal of New York State. Albany, NY:J.B. Lyons Company. 